\title{
Association of the scuttle fly Megaselia leucozona Schmitz (Diptera: Phoridae) with sweat bees (Hymenoptera: Halictidae), with a description of the male fly
}

\author{
Carlo Polidori, R. Henry L. Disney, Roberto Boesi \& Francesco Andrietti
}

Polidori, C., Disney, R. H. L., Boesi, R. \& Andrietti, F. 2005: Association of the scuttle fly Megaselia leucozona Schmitz (Diptera: Phoridae) with sweat bees (Hymenoptera: Halictidae), with a description of the male fly. - Entomol. Fennica 16: 144-150.

Megaselia leucozona Schmitz (Diptera, Phoridae) is reported from nests of Lasioglossum malachurum Kirby and Halictus scabiosae (Rossi) in Central Italy. The flies patrolled two nesting sites of the hosts and sometimes mated close to their nest entrances before entering. Observations agree with the general behaviour reported for other Megaselia species associated with fossorial bees and wasps. The hitherto unknown male of M. leucozona is described, and the original description of a female is augmented and modified. This is the first report of a scuttle fly associated with nests of Halictidae in the Palaearctic Region.

C. Polidori, Dipartimento di Biologia, Sezione di Zoologia Citologia, Università Degli Studi di Milano, Via Celoria 26, 20133 Milano, Italy; E-mail: cpolidori @)virgilio.it

R. H. L. Disney, Museum of Zoology, University of Cambridge, Downing Street, Cambridge CB2 3EJ, United Kingdom

R. Boesi, Dipartimento di Biologia Evolutiva, Università degli Studi di Siena, Via A. Moro 4, 35100 Siena, Italy

Francesco Andrietti, Dipartimento di Biologia, Sezione di Zoologia Citologia, Università Degli Studi di Milano, Via Celoria 26, 20133 Milano, Italy

Received 6 September 2004, accepted 15 December 2005

\section{Introduction}

Scuttle flies (Diptera: Phoridae) are a large group of small insects often associated with Hymenoptera, of which they are parasitoids, kleptoparasites, predators, facultative or obligate, or scavengers (Disney 1994). Generally their biology is poorly known, and most of the research concern aspects of the reproductive behaviour (Binns 1980, Miller 1984, Sivinski 1988, Wcislo 1990, Polidori et al. 2004). While most reported associations of Hymenoptera with Phoridae con- cern ants (Disney 1994), some studies reveal a widespread association also with bees and wasps (e.g. Coville \& Griswold 1983, 1984, Disney \& Bartareau 1995, Disney et al. 2000, 2003, Polidori et al. 2001).

With regard to previous records of scuttle flies associated with Halictidae (Hymenoptera), females of the Nearctic and Neotropical Phalacrotophora halictorum (Melander \& Brues) have been observed to enter the nests of three genera of Halictidae, including three species of Lasioglossum Curtis. The flies typically mate near the 
entrances of the bee nests, after which the females enter the nest to oviposit. The larvae appear to be primarily pollen feeders, but they also scavenge faecal material or become facultative predators of the larvae of their bee hosts (Melander \& Brues 1903, Borgmeier 1963, Batra 1965, Eickwort \& Eickwort 1969, 1971, Wcislo 1990). The Neotropical Megaselia neocorynurae has also been reported feeding on the pollen stores of Halictidae (Gonzalez et al. 2002).

Our aims are twofold. Firstly, we describe the hitherto unknown male of M. leucozona, and modify the original description of a female. Secondly, we report observations on flies patrolling nesting sites of two host bee species and their mating behaviour.

\section{Material and methods}

Megaselia leucozona males and females were observed flying through two nesting sites of fossorial bees located near Alberese (Grosseto), a little town $10 \mathrm{~km}$ from the sea coast, in the Maremma Regional Park (Tuscany, Italy) (42\%40'5" $\mathrm{N}, 11^{\circ} 6$ '23"E). One site (A) was colonized by the primitively eusocial bee Lasioglossum malachurum Kirby, while the other site (B) was colonized by three species: L. malachurum, the halictine eusocial bee Halictus scabiosae (Rossi), and the digger wasp Cerceris rubida (Jurine). The two sites were ca. $7 \mathrm{~km}$ apart. The site A was more distant from the sea than $\mathrm{B}$ and consisted of a trail in a mediterranean wood, while B consisted of the boundary of a maize field. In B we found a few nests of C. rubida, at the time likely to be the beginning of its nesting period. Most nests belonged to the two halictine bees, both in an advanced phase of the nesting cycle. Observations were made in May 2003 (site A) and May-June 2004 (both A and B).

\section{Results}

Scuttle flies were repeatedly caught at the nests of L. malachurum and H. scabiosae. Initially, only males were procured. The specimens resembled Megaselia pygmaea (Zetterstedt), but they keyed to a subgroup whose recognition typically re- quires females. This complex includes $M$. oxybelorum Schmitz, which we have previously reported as a kleptoparasite of the digger wasps Cerceris arenaria (L.) and Philanthus triangulum Fabr. (Crabronidae) in Italy (Polidori et al. 2001, unpubl.). The eventual procurement of the female flies at nests of L. malachurum (collected in 2004) allowed identification of this species as being M. leucozona Schmitz, previously only known from a single female from Daghestan. In the Taxonomy section, the description of the hitherto unknown male and the recognition of this species in both sexes are discussed, and in the Field observations section behavioural notes on this species are reported.

\subsection{Taxonomy}

\section{Megaselia leucozona Schmitz \\ Megaselia leucozona Schmitz, 1930: 67.}

This species belongs to a complex whose males all resemble M. pygmaea. Indeed a feature of this cluster is that the females are distinctive but the males are easily confused, especially when mounted on pins instead of on slides. The description of some species from one sex only has compounded the problems of species recognition. An attempt to improve this situation was the provision of keys to both sexes, albeit some species being included on the basis of published descriptions only (Disney 1988). The latter, based on pinned specimens, placed too much reliance on small differences in details of the wings that proved then and subsequently (Disney 2003) to be more variable than had been supposed. Indeed, M. leucozona was described from a single female from a series of three closely related species reared from locust egg pods in Daghestan, the other two species being known in both sexes. However, both the other species were subsequently synonymised (Disney 1988) with other species, M. brevissima (Schmitz) and M. oxybelorum Schmitz, that are both now recorded from Italy.

Description. Female. From Schmitz's (1930) description, it seems that the holotype was still somewhat teneral and therefore partly paler than when fully pigmented. Postpedicels with about 

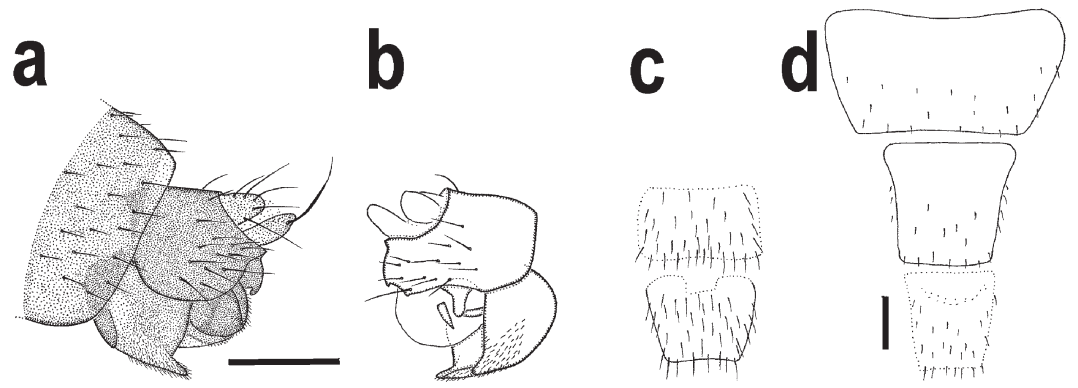

Fig. 1. Megaselia leucozona. - a. Left side of male hypopygium. - b. Right sides of male epandrium and hypandrium. - c-d. Female abdominala tergites; (c) T5-T6, (d) T2-T4. Scale bars $0.1 \mathrm{~mm}$.

fifteen SPS vesicles, the largest being subequal to diameter of socket of lower SA bristle. The brown labrum up to $1.2 \times$ as broad as postpedicel. Abdominal tergites $2-6$ as Fig. $1 \mathrm{c}$ and $1 \mathrm{~d}, \mathrm{~T} 2$ being dark brown, T3 paler brown, T4 straw yellow with an irregular pale yellowish brown transverse band in front of the most anterior hairs, T5 is straw yellow, and while Schmitz stated that T6 is brown it is more yellowish brown to brownish yellow. It may appear darker if the terminal segments are withdrawn beneath it. Venter with segments 1-3 and anterior border above and to about halfway on flanks of 4 greyish brown. The rest of segment 4 and all of 5 yellow and 6 mainly greyish brown but with yellow patches on flanks in anterior half. Dufour's crop mechanism about $2.4 \times$ as long as greatest breadth and strongly convex behind. With four rectal papillae. The femora and tibiae are darker than stated by Schmitz, being light brown with straw yellow or paler patches. Wings 1.2-1.4 mm long. Costal index 0.34-0.38. Costal ratios 3.7-4.3:1.1-1.3: 1 . Costal cilia (of section 3) $0.07 \mathrm{~mm}$ long. Vein Sc fades away before reaching vein 1 . A fine hair at base of vein 3. 2-3 (usually 2) bristles on axillary ridge, the outer two being longer than costal cilia.

Most of the females were gravid and carried 6-12 (typically 8) eggs. The eggs when mature are smooth and elongated, measuring 0.45-0.49 $\times 0.19-0.23 \mathrm{~mm}$. There was no apparent relationship between size (as measured by the length of the hind femur) and egg batch number.

Male. Frons similar to female. Cheek with 3-6 bristles and jowl with 1-3 longer ones. Postpedicels subglobose, dark brown, with similar but up to twice as many SPS vesicles as in female (the number being very variable). Palps yellowish brown, with 5-6 bristles and as many hairs. Labrum straw yellow lightly tinged brown and only about $0.6 \times$ as wide as postpedicel. Labella a little darker on top, with about two dozen short spinules below each. Thorax similar to female, with two notopleural bristles and no cleft in front of these. Scutellum with an anterior pair of small hairs (smaller than hairs at rear of scutum, and therefore much smaller than those of female) and a posterior pair of bristles. Abdominal tergites brown with small hairs, those at rear of T6 being only a little longer than rest (Fig. 1a). Venter brown, and with a few hairs below segments 3-6. Hypopygium brown with paler brown anal tube, apart from almost colourless lobes of hypandrium, and as Fig. 1a. Right lobe of hypandrium clearly shorter than left lobe (Fig. 1b). With only two rectal papillae. Legs similar to female except the hind femur is broader and, after the first 4-6, the hairs below its basal half are clearly longer and stronger than those of the anteroventral row in the outer half. Hind tibia with spinules of apical combs simple. Wings 0.8-1.2 mm long. Costal index 0.32-0.38. Costal ratios 3.4-4.9:0.9-1.4: 1. Costal cilia (of section 3) $0.05-0.07 \mathrm{~mm}$ long. Otherwise wing and haltere as female.

Recognition. Because the femora are darker than stated by Schmitz, instead of running to couplet 3 (as had been inferred from the published description of the female) the males will run to couplet 11 of the keys to the Palaearctic members of this complex (Disney 1988). This couplet distinguishes $M$. oxybelorum Schmitz from $M$. exsecta Schmitz plus $M$. intersecta Schmitz. The male of the latter is not known and the description of the male of $M$. exsecta is inadequate by modern standards. Indeed these four species are only reliably distinguished in the female sex until the male hypopygia of $M$. exsecta and $M$. intersecta are properly described. The hypopygium of $M$. oxy- 
belorum is depicted in Fig. 2a-b. It has the left lobe of the hypandrium smaller than the right lobe, whereas the reverse is the case in $M$. leucozona (Figs. 1a-b). In the keys to the males of British Megaselia (Disney 1989) those of M. leucozona run to couplets 219 and 220, the similar species being covered by the 1988 keys.

\subsection{Field observations}

The observed individuals were seen to attempt entry or to enter nests of three different possible hosts: L. malachurum ( 8 out of 8 recorded events in site A, $51 \%$ recorded events in site $\mathrm{B}, n=45)$, H. scabiosae ( $44 \%$ recorded events in site $\mathrm{B}, n=$ 45), C. rubida ( $5 \%$ recorded events in site $\mathrm{B}, n=$ 45).

In total, we recorded 15 pairs of M. leucozona flying in copula and 38 individuals flying alone. In particular, no mating pairs were observed in A, while in B we recorded 5 pairs in copula at $L$. malachurum nests (of which one entered the nest) and 6 pairs in copula at $H$. scabiosae nests (of which 4 entered the nest); the other 4 flies in copula were seen flying over the nesting site, but not close to a particular bee nest. We observed 14 single individuals of $M$. leucozona at $H$. scabiosae nests (of which 5 entered the bee nests), 22 single individuals at L. malachurum nests (of which 7 entered the bee nests). The times spent in the bee nests by the scuttle flies, with further informations on the visits in the nests, are summarized in Table 1.

Two individuals were seen to enter $C$. rubida nests. In these cases, scuttle flies remained in the nests for 3 and 2 seconds only.

Ten recorded events refer to a single $H$. scabiosae nest and 4 to a single $L$. malachurum nest. These two nests were very close one to the other (ca. $5 \mathrm{~cm}$ ) and many pairs flying in copula were observed trying to enter both nests in quick succession, the immediate choice relating to the presence of the bee guard at the entrance that in most cases drove back the flies. Also individuals flying alone were seen to be interested, in quick succession, in the nests of both bees and, in one case, in both a $L$. malachurum nest and a $C$. rubida nest. Shifting between different nests prior to entering one is probably not only due to searching behav-

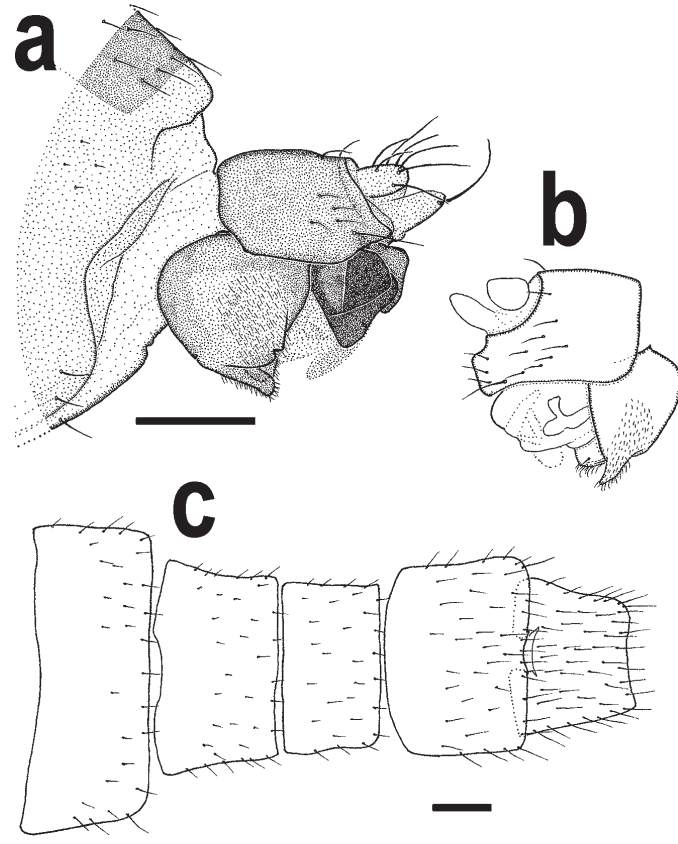

Fig. 2. Megaselia oxybelorum. - a. Left side of male hypopygium. $-b$. Right sides of male epandrium and hypandrium. - c. Female abdominal tergites 2-6. Scale bars $0.1 \mathrm{~mm}$.

iour, but also to the fact that many times (36) a bee guard blocked the entrance to the nest. In particular, we observed 3 visits out of 20 attempts on L. malachurum guarded nests and 9 visits out of 14 attempts on $H$. scabiosae guarded nests. In the two cases concerning $C$. rubida attempts, despite the presence of the wasp on the entrance, the fly entered successfully.

\section{Discussion}

The mostly straw-yellow abdominal female tergites 4 and 5, contrasting with the mainly brown colour of the rest of the tergites, is a striking feature of the female M. leucozona, as reflected by its name. It is, therefore, curious to note that the females of the Neotropical M. neocoynurae, whose larvae are associated with the pollen stores of Halictidae (Gonzalez et al. 2002), also possess a similar pale band, but covering the posterior half of T5 and anterior half of T6. This difference in position, together with the fact that $M$. neocoynurae and $M$. leucozona are evidently only 
Table 1. Events referring to Megaselia leucozona entering the nests of its host bees. Fly characteristics are as follows: "Sex" (Female or Male), "Solar hour (in 24-h), "Time in (s)" = time spent in the host nest, Single = a single specimen observed, "Copula" = a copulating pair observed.

\begin{tabular}{lccccc}
\hline \multirow{2}{*}{ Host } & Fly & & & & \\
& Sex & Solar hour & Time in (s) & Single & Copula \\
\hline \multirow{4}{*}{ m. malachurum } & $\mathrm{M}$ & $10: 10$ & - & $\mathrm{X}$ & - \\
& $\mathrm{M}$ & $10: 40$ & 4 & $\mathrm{X}$ & - \\
& $\mathrm{M}$ & $16: 33$ & - & $\mathrm{X}$ & - \\
& $\mathrm{M}+\mathrm{F}$ & $16: 47$ & - & - & $\mathrm{X}$ \\
& $\mathrm{M}$ & - & 3 & $\mathrm{X}$ & - \\
& $\mathrm{M}$ & - & 4 & $\mathrm{X}$ & - \\
& $\mathrm{M}$ & - & 17 & $\mathrm{X}$ & - \\
H. scabiosae & $\mathrm{M}$ & - & 1 & $\mathrm{X}$ & - \\
& $\mathrm{M}$ & $10: 00$ & 4 & $\mathrm{X}$ & - \\
& $\mathrm{M}$ & $10: 35$ & 3 & $\mathrm{X}$ & - \\
& $\mathrm{M}$ & $16: 30$ & 12 & $\mathrm{X}$ & - \\
& $\mathrm{M}$ & $17: 05$ & - & $\mathrm{X}$ & - \\
& $\mathrm{M}$ & $17: 06$ & 12 & $\mathrm{X}$ & - \\
& $\mathrm{M}+\mathrm{F}$ & $16: 27^{*}$ & 2 & - & $\mathrm{X}$ \\
& $\mathrm{M}+\mathrm{F}$ & $16: 27^{*}$ & 10 & - & $\mathrm{X}$ \\
& $\mathrm{M}+\mathrm{F}$ & $16: 33$ & - & - & $\mathrm{X}$ \\
& $\mathrm{M}+\mathrm{F}$ & $16: 35$ & - & - & $\mathrm{X}$ \\
& $\mathrm{M}+\mathrm{F}$ & $16: 54$ & - & - & $\mathrm{X}$ \\
\hline
\end{tabular}

* $=$ information concerns both observed specimens

distantly related, may indicate that this contrasting, pale transverse band on the abdomen has evolved independently in the two species. Whether this is merely fortuitous, or the pale transverse band serves some function in relation to the interaction between the flies and their bee hosts, is unknown.

The shape of mature eggs, smooth and elongated, resembles that of M. brevissima (Schmitz) and M. ultrabrevis Schmitz mature eggs [figures 4B and 5I in Disney (1988)]. This contrasts with a recorded batch size of only two eggs in $M$. oxybelorum, whose eggs are almost spherical [figure 5M in Disney (1988)], and M. stenoterga Disney, with a more oval egg [figure 5L in Disney (1988)], and with batch sizes of 10, 14 and 20 eggs in M. ultrabrevis, M. curtineura (Brues) and M. brevissima, respectively (Disney 1988). $M$. curtineura larvae are well-known polyphagous saprophages (omnivores). M. leucozona, M. brevissima and $M$. oxybelorum were the three species reared from locust egg pods (Schmitz 1930), but it seems that only damaged egg pods are attacked by these Phoridae (Greathead 1963). $M$. oxybelorum has also been reared from paralysed fly prey of the larvae of the digger wasp Oxybelus uniglumis (L.) (Crabronidae) and has been observed to visit nests of other two solitary wasps C. arenaria and P. triangulum (Chevalier 1925, Schmitz 1928, Polidori et al. 2001, unpubl.). It seems likely that these species reared from both damaged locust egg pods and collected from the burrows of bees and wasps are seeking concealed moribund or paralysed insect prey for their larvae. Whether the larvae are also feeding on the pollen stores of the host is not known. The significance of the differences in the recorded egg-batch sizes among these related scuttle-fly species remain to be explained, and also the apparent host specificity of M. leucozona with respect to its bee hosts, despite the single specimen previously reared from a locust egg pod.

With the scarce recorded biological data, we could compare the observed behaviour of $M$. leucozona to what we know on the biology of other species of Megaselia associated with fossorial Hymenoptera. In particular, the reproductive behaviour performed by M. leucozona on 
the nesting site of its hosts, characterized by frequent matings close to the host nests, agrees with that performed by Megaselia andrenae Disney and $M$. oxybelorum, kleptoparasites of the communal bee Andrena agilissima Scopoli and the wasp $P$. triangulum, respectively (Polidori et al. 2004, unpubl.). The apparent lack of copulaations of $M$. oxybelorum at the nesting site of $C$. arenaria was probably due to the very few individuals observed in that case (Polidori et al. 2001). Frequent matings were also observed by Wcislo (1990) for P. halictorum at a nesting aggregation of $L$. figueresi. Moreover, individuals flying alone were males, as the collection of the females occurred only through the capture of individuals in copula (Table 1). This predominance of males over females among individuals flying alone was recorded also with the collection of $M$. andrenae specimens at the nesting site of A. agilissima (Polidori et al. 2004), and it could reflect a more cryptic behaviour of females during the patrolling of the host's nesting site or, as observed in other Megaselia spp. (Binns 1980), a male-biased sex ratio.

Despite the weak evidence, we presume M. leucozona to be an actual kleptoparasite at least of L. malachurum, a hypothesis supported by the fact that this scuttle fly was present on two different nesting sites of this bee, and, in one of these, in two subsequent nesting seasons. Previous information on the biology and hosts of this and other Megaselia species support the hypothesis of a generalist choice in the exploitation of bee and wasp nest contents.

As far as we know, these observations on $M$. leucozona are the second report on a Megaselia species associated with halictid bees (Gonzalez et al. 2002), and the first report on a scuttle fly associated with sweat bees in the Palaeartic Region.

Acknowledgements. Our thanks are due to Cristina Papadia and Stefania Bevacqua for field assistance. Part of the work was supported by a grant FIRB (Fondo per gli Investimenti della Ricerca di Base) RBAU019H94-001 (2001). RHLD's studies of Phoridae are funded by the Isaac Newton Trust (Trinity College, Cambridge).

\section{References}

Batra, S. W. T. 1965: Organisms associated with Lasioglossum zephyrum (Hymenoptera: Halictidae). Journal of the Kansas Entomological Society 38: 367-389.

Binns, E. S. 1980: Mating behaviour, fecundity and feeding in the mushroom phorid, Megaselia halterata (wood) (Dipt.). - Entomologist's Monthly Magazine 116: 45-58.

Borgmeier, T. 1963: Revision of the North American phorid flies. Part I. The Phorinae, Aenigmatiinae and Metopininae, except Megaselia (Diptera, Phoridae). — Studia Entomologica Petropolis 6: 1-256.

Chevalier, L. 1925: Phora pygmaea Zett. Diptère mangeur de mouches. - Bulletin de la Société de Sciences de Seine-et-Oise 6: 93-96. [In French.]

Disney, R. H. L. 1988: The Palaearctic species resembling Megaselia pygmaea (Diptera, Phoridae), including two new species. - Annales Entomologici Fennici 54: 153-161.

Disney, R. H. L. 1989: Scuttle Flies - Diptera Phoridae Genus Megaselia. - Handbooks for the Identification of British Insects 10 (8): 1-155.

Disney, R. H. L. 2003: Revisionary notes on European Phoridae (Diptera). - Bonner Zoologisches Beiträge 50: 293-304.

Disney, R. H. L., Scanni, B., Scamoni, E. \& Andrietti, F. 2000: A new species of scuttle fly (Diptera: Phoridae) whose larvae are kleptoparasites of a bee (Hymenoptera: Andrenidae). - Giornale Italiano di Entomologia 9: 99-104 (1998).

Eickwort, G. C. \& Eickwort, K. R. 1969: Aspects of the biology of Costa Rican halictine bees, I. Agapostemon nasutus (Hymenoptera: Halictidae). - Journal of the Kansas Entomological Society 42: 421-452.

Eickwort, G. C. \& Eickwort, K. R. 1971: Aspects of the biology of Costa Rican halictine bees, II. Dialictus umbripennis and adptations of its caste structure to different climates. - Journal of the Kansas Entomological Society 44: 343-373.

Gonzalez, V. H., Brown, B. V. \& Ospina, M. 2002: A new species of Megaselia (Diptera: Phoridae) associated with brood provisions of nests of Neocorynura (Hymenoptera: Halictidae). - Journal of the Kansas Entomological Society 75: 73-79.

Greathead, D. J. 1963: A review of the insect enemies of Acridoidea. (Orthoptera). - Transactions of the Royal Entomological Society of London 114: 437-517.

Melander, A. L. \& Brues, C. T. 1903: Guests and parasites of the burrowing bee Halictus. - Biological Bulletin, Marine Biological Laboratory, Woods Hole, Mass 5: $1-27$.

Polidori, C., Disney, R. H. L. \& Andrietti, F. 2001: Some behavioural observations on Megaselia oxybelorum (Diptera: Phoridae), a new kleptoparasite of Cerceris arenaria (Hymenoptera: Sphecoidea: Philanthidae). 
- British Journal of Entomology and Natural History 14: 93-95.

Polidori, C., Disney, R. H. L. \& Andrietti, F. 2004: Some observations on the reproductive biology of the scuttle fly Megaselia andrenae (Diptera: Phoridae) at the nesting site of its host Andrena agilissima (Hymenoptera: Andrenidae). - European Journal of Entomology 101: 337-340.

Schmitz, H. 1928: Verslag der Maandelijksche vergadering 5. September L. L. Megaselia oxybelorum n. sp. - Natuurhistorisch Maandblad 17: 121-122, 131-132.

Schmitz, H. 1930: Phoriden aus Eipaketen von Locusta migratoria in Daghestan. — Natuurhistorisch Maandblad 19, 67-69.

Wcislo, W. T. 1990: Parasitic and courtship behavior of Phalacrotophora halictorum (Diptera: Phoridae) at a nesting site of Lasioglossum figueresi (Hymenoptera: Halictidae). - Revista de Biologia Tropical 38 (2A): 205-209. 